\title{
Adiponectin limits differentiation and trophoblast invasion in human endometrial cells
}

\author{
Fabien Duval1, Esther Dos Santos1,2, Hadia Moindjie1, Valérie Serazin1,2, \\ Nelly Swierkowski-Blanchard1,3, François Vialard1,3 and Marie-Noëlle Dieudonné1 \\ ${ }_{1}^{1 G I G}$ - EA 7404, Université de Versailles-Saint-Quentin-en-Yvelines, Université Paris-Saclay, Unité de \\ Formation et de Recherche des Sciences de la Santé Simone Veil, Montigny-le-Bretonneux, France \\ ${ }^{2}$ Service de Biologie Médicale, Centre Hospitalier de Poissy-Saint Germain, Poissy, France \\ ${ }^{3}$ Département de Biologie de la Reproduction, Cytogénétique, Gynécologie et Obstétrique, Centre Hospitalier \\ de Poissy-Saint Germain, Poissy, France
}

Correspondence should be addressed to M-N Dieudonné Email marie-noelle.dieudonne@ uvsq.fr

\begin{abstract}
Successful human embryo implantation requires a proper differentiation of endometrial stromal cells (ESCs) into decidual cells, during a process called decidualization. ESCs express specific molecules, such as prolactin, insulin-like growth factor-binding protein-1 (IGFBP-1) and connexin-43. Decidual cells are also involved in the control of trophoblast invasion, by secreting various factors, such as matrix metalloproteinases (MMPs) and tissue inhibitors of metalloproteinases (TIMPs). Adiponectin is an adipokine with insulin-sensitizing, anti-inflammatory and anti-proliferative effects. At the embryomaternal interface, adiponectin promotes differentiation and invasion of human trophoblastic cells. We hypothesize that the effects of adiponectin on endometrium could counteract its pro-invasive effects previously described in the human trophoblast. In this context, we have firstly demonstrated that adiponectin downregulates IGFBP-1 and connexin-43 mRNA expressions, as well as prolactin secretion in ESCs, suggesting an anti-differentiative effect of adiponectin. Secondly, we found that invasive capacities of trophoblastic cell line HTR-8/SVneo are reduced in the presence of conditioned media from ESC cultured in the presence of adiponectin. Adiponectin's anti-invasive action is associated with a decreased activity of MMP-2 and MMP-9, and an increased TIMP-3 mRNA expression in ESCs. Finally, adiponectin receptors (ADIPOR1 and ADIPOR2) knockdown abolishes the anti-differentiative and anti-invasive effects of adiponectin in human ESCs. Altogether, our results suggest that adiponectin reduces the decidualization process and inversely induces the production of endometrial factors that limit trophoblast invasion. Thus, through a dual control in trophoblast and endometrial cells, adiponectin appears as a pivotal actor of the embryo implantation process.
\end{abstract}

Journal of Molecular Endocrinology (2017) 59, 285-297

\section{Introduction}

Human embryo implantation is a multi-step process that begins with apposition of trophoblastic cells from a competent blastocyst to the maternal endometrium. This apposition occurs during the 'window of implantation', a short period of uterine receptivity corresponding to the mid-secretory phase of the menstrual cycle

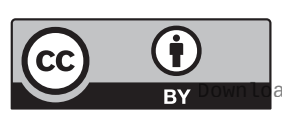


(Diedrich et al. 2007). After the blastocyst has attached to the endometrial epithelium, its extravillous trophoblasts (EVTs) penetrate into the endometrial stroma and acquire an invasive phenotype resulting in the placenta anchoring in the endometrium (Lunghi et al. 2007).

During trophoblast invasion, EVTs secrete large amounts of matrix metalloproteinases (MMPs) (Burrows et al. 1996). The actions of MMP-2 and MMP-9 are crucial for trophoblast invasion (Staun-Ram et al. 2004). Indeed, these gelatinases are able to degrade the major component of the endometrial extracellular matrix (ECM) i.e. collagen IV (Burrows et al. 1996). MMP activity is regulated by specific tissue inhibitors of metalloproteinases (TIMPs), which bind and inactivate MMPs with a 1:1 stoichiometry (Huppertz et al. 1998). Thus, correct regulation of the MMP/TIMP balance in EVTs is essential for an appropriate embryo implantation (Nissi et al. 2013). Trophoblast invasion also requires adequate endometrial receptivity (Singh et al. 2011). This is characterized by morphological, biochemical and vascular modifications, including (i) the appearance of epithelial pinopodes, (ii) the modulated expression of cytokines, growth factors and adhesion molecules (particularly the upregulation of epithelial $\alpha \mathrm{V}$ - and $\beta 3$-integrins), (iii) the disappearance of an adhesive molecular surface (loss of mucin-1 and mucin-12) and (iv) the decidualization of endometrial stromal cells (ESCs). Decidualization occurs in response to the ovarian hormones, 17 $\beta$-estradiol (E2) and progesterone (P4). It is accompanied by the secretion of prolactin and insulinlike growth factor-binding protein-1 (IGFBP-1), and the expression of the gap junction connexin-43 (CX-43) in human ESCs (Brar et al. 1995, Yu et al. 2011). Decidual ECM remodeling events have also been observed. These processes are associated with MMP-2,-9 secretion and the modulation of TIMP-1,-2,-3 expression in human ESCs (Zhang \& Salamonsen 1997, Estella et al. 2012, Tapia-Pizarro et al. 2013). This type of ECM remodeling enhances ESC motility and thus facilitates trophoblastic infiltration into the endometrial stroma (Grewal et al. 2008). Decidual ECM remodeling is a complex process, tightly controlled by factors intrinsically produced by both placental and decidual cells (Sharma et al. 2016). For example, human chorionic gonadotropin (hCG) and tumor necrosis factor alpha (TNF- $\alpha$ ) facilitate EVT migration by enhancing endometrial MMP-2,-9 activities and by inhibiting endometrial TIMP-1 secretion (Haider \& Knöfler 2009, Tapia-Pizarro et al. 2013). Conversely, the antifungal antibiotic trichostatin A limits trophoblast invasion by increasing the production of TIMP-1,-3 by
ESCs and reducing the activity of endometrial MMP-2,-9 (Estella et al. 2012). Hence, the local MMP/TIMP balance, at the invasion site, requires an appropriate interaction between trophoblasts and ESCs.

Adiponectin is a $30 \mathrm{kDa}$ cytokine, predominantly produced by adipose tissue (Kern et al. 2003). Adiponectin exerts its action via two specific receptors (ADIPOR1 and ADIPOR2) containing seven transmembrane domains but which are structurally and functionally distinct from G-protein-coupled receptors (Yamauchi et al. 2003a). By binding to ADIPORs, adiponectin activates a variety of targets, such as protein kinase A, phosphoinositide-3 kinase, mitogen-activated protein kinase and most notably, the AMP-activated protein kinase through which adiponectin exerts its insulin-sensitizing effects (Yamauchi et al. 2003a, Campos et al. 2008). This adipokine has also been shown to exert anti-inflammatory, anti-angiogenic, antiatherosclerotic, anti-proliferative and pro-apoptotic roles in various cell types (Yamauchi et al. 2003b, Dieudonne et al. 2006, Duval et al. 2016).

During pregnancy, adiponectin seems to act as an endo/paracrine signal at the embryo-maternal interface. It is now established that adiponectin is not produced by human trophoblastic cells but seems to be expressed in human endometrium (Takemura et al. 2006, Benaitreau et al. 2010a, Dos Santos et al. 2012). ADIPOR1 and ADIPOR2 are expressed in human placenta and endometrium (Takemura et al. 2006, Benaitreau et al. 2009). A growing body of evidence has highlighted adiponectin role in the establishment of a functional placenta (Benaitreau et al. 2010b). Our laboratory has shown that adiponectin promotes human trophoblast invasion by enhancing MMP-2,-9 activities and downregulating TIMP-2 mRNA expression (Benaitreau et al. 2010a).

However, little is known about adiponectin effects in human endometrium. A study showed that expression of ADIPOR1 and ADIPOR2 peaks in the mid-secretory phase of menstrual cycle (Takemura et al. 2006). We have also observed significantly low endometrial expression of ADIPOR1 and ADIPOR2 in women with unexplained recurrent implantation failure relative to fertile women (Dos Santos et al. 2012). In vitro, adiponectin exerts an anti-proliferative action by promoting cell death (Bohlouli et al. 2013). Taken as a whole, these data strongly suggest that adiponectin plays a crucial role during embryo implantation. With a view to better understand embryomaternal dialog in the early stages of pregnancy, we studied the in vitro effects of adiponectin on (i) the human ESC decidualization program and (ii) the endometrial control of trophoblast invasion.

Published by Bioscientifica Ltd. 


\section{Materials and methods}

\section{Materials}

Dulbecco's Modified Eagle's Medium and Ham F-12 Nutrient Mix (DMEM/F12), Roswell Park Memorial Institute (RPMI) medium, progesterone, E2, penicillin, streptomycin, DNase type I, EDTA, leupeptin, aprotinin, 4-(2-aminoethyl)-benzene-sulfonyl fluoride (AEBSF), sodium fluoride and bovine serum albumin (BSA) were purchased from Sigma Chemical Co. Fetal calf serum (FCS) was purchased from Gibco (Invitrogen). Recombinant human adiponectin was provided by R\&D Systems Europe Ltd. Superscript III RNase H-RT and primers were from Invitrogen, and RNase inhibitor was obtained from AMRESCO (Solon, OH, USA). Nucleospin RNA II kit was obtained from Machery-Nagel (Düren, Germany). Trypsin was provided by Difco Laboratories (Detroit, MI, USA). Matrigel was obtained from BD Biosciences (Le Pont-deClaix, France) and collagenase A was from Boehringer (Mannheim, Germany). The suppliers of the various antibodies used are described in the corresponding paragraphs below.

\section{Study population and tissue collection}

A total of 23 normally cycling women aged 27-40 undergoing biopsy for fertility evaluation, were recruited into the present study. Endometrial tissues were obtained during the window of implantation. Patients with low endometrial volume $(<2 \mathrm{~cm})$ or presence of submucous fibroma or polyps were excluded. A good hormonal reserve and normal responses to ovarian stimulation were also included as additional criteria. This study was approved by the local investigational review board (Comité Consultatif de Protection des Personnes dans la Recherche Médicale, approval reference protocol 01-78). All participants provided their informed consent before tissue sampling.

\section{Human ESC culture}

Human ESCs were isolated and cultured as described by González and coworkers (Gonzalez et al. 1999). Briefly, tissue samples were minced into small pieces and digested in a two-step process. Tissues were incubated for $1 \mathrm{~h}$ at $37^{\circ} \mathrm{C}$ in a phenol-red-free DMEM/F12 medium containing collagenase $(0.1 \%)$, DNase type I $(0.0005 \%)$, penicillin $(10 \mu \mathrm{g} / \mathrm{mL})$ and streptomycin $(100 \mathrm{U} / \mathrm{mL})$.
The supernatant was filtered through a $100 \mu \mathrm{m}$ nylon screen and then centrifuged at $200 \boldsymbol{g}$ for $10 \mathrm{~min}$. A second enzymatic digestion was performed on undigested tissue for $10 \mathrm{~min}$ at $37^{\circ} \mathrm{C}$ in DMEM/F12 medium-containing trypsin $(0.25 \%)$, DNase type I $(0.1 \%)$, EDTA $(0.03 \%)$, penicillin $(10 \mu \mathrm{g} / \mathrm{mL})$ and streptomycin $(100 \mathrm{U} / \mathrm{mL})$. The digested tissue was filtered through a $40 \mu \mathrm{m}$ nylon screen and then centrifuged at $200 \boldsymbol{g}$ for $10 \mathrm{~min}$. Cell pellets from both digestions were pooled and centrifuged at $200 \boldsymbol{g}$ for $10 \mathrm{~min}$.

Cells were cultured in DMEM/F12 medium supplemented with streptomycin $(10 \mu \mathrm{g} / \mathrm{mL})$, penicillin $(100 \mathrm{U} / \mathrm{mL})$ and FCS $(10 \%)$ at $37^{\circ} \mathrm{C}$ in a $5 \% \mathrm{CO}_{2}$ and $95 \%$ air atmosphere. When the cells reached confluence, they were cultured in the presence or absence of adiponectin $(25 \mathrm{ng} / \mathrm{mL}$ and $250 \mathrm{ng} / \mathrm{mL})$ in differentiation medium containing DMEM/F12 with E2 $\left(10^{-8} \mathrm{M}\right)$, P4 $\left(10^{-6} \mathrm{M}\right)$, charcoal-stripped FCS (2\%), penicillin $(10 \mu \mathrm{g} / \mathrm{mL})$ and streptomycin $(100 \mathrm{U} / \mathrm{mL})$ for 15 days. Media were changed every 2 days.

\section{Immunocytochemistry}

Endometrial cells were washed three times in phosphatebuffered saline (PBS) and fixed with paraformaldehyde (4\%) for $30 \mathrm{~min}$ at room temperature. Cells were permeabilized for 5 min with PBS-Triton X-100 (0.2\%). Non-specific binding was prevented by incubation with BSA (3\%) in PBS for $1 \mathrm{~h}$ at room temperature. Vimentin (mouse anti-human monoclonal, 1:50, clone V9, 7902917, Ventana Medical Systems, Tucson, AZ, USA) and pan-cytokeratin (mouse anti-human monoclonal, 1:50, clone KL1, Mob 191-05, Diagnostic Biosystems, Pleasanton, CA, USA) were chosen as stromal and epithelial markers, respectively (Merviel et al. 1995). The labeled cells were then rinsed with PBS and incubated with an Alexa-488-conjugated goat-antimouse secondary antibody (1:400, $\mathrm{A}_{\max } / \mathrm{E}_{\max }: 488 / 519$, A-11001, Molecular Probes, Thermo Fisher Scientific Inc.) for $1 \mathrm{~h}$ at room temperature. Cell nuclei were counterstained with $1 \mu \mathrm{g} / \mathrm{mL}$ Hoechst 33258 (SigmaAldrich). As a negative control, endometrial cells were processed in the absence of primary antibody. Immunostained samples were observed using an automated inverted microscope (ScanR, Olympus, Rungis, France). Positive cells were counted on five randomly selected fields by the post-imaging procedure in ImageJ software. http://jme.endocrinology-journals.org DOI: 10.1530/JME-17-0046
(C) 2017 The authors Printed in Great Britain
Published by Bioscientifica Ltd 


\section{Invasion assay for HTR-8/SVneo cells co-cultured with ESC culture medium}

The invasiveness of trophoblastic cells in response to ESCsecreted molecules was assessed using the HTR-8/SVneo immortalized EVT cell line, kindly provided by Dr Nadia Alfaidy (CEA Grenoble, France) in agreement with Dr Charles Graham. HTR-8/SVneo cells were cultured in RPMI medium supplemented with HEPES $1 \mathrm{M}(2 \%)$, penicillin $(100 \mathrm{U} / \mathrm{mL})$, streptomycin $(100 \mu \mathrm{g} / \mathrm{mL})$ and FCS (10\%) until they reached confluence. Invasion assays were performed in 24-well plates containing Matrigel-coated polycarbonate membrane (pore size: $8 \mu \mathrm{m}$ ) invasion chamber inserts (Greiner Bio-One SAS, Courtaboeuf, France), according to the modified protocol from Tapia-Pizarro and coworkers (Tapia-Pizarro et al. 2013). HTR-8/SVneo cells were suspended $\left(5 \times 10^{4}\right.$ cells per well) in $250 \mu \mathrm{L}$ of conditioned medium (CM) from 15-day-decidualized ESCs treated or not with adiponectin $(25 \mathrm{ng} / \mathrm{mL}$ and $250 \mathrm{ng} / \mathrm{mL})$. Media containing only E2 and P4 in the absence or presence of adiponectin $(25 \mathrm{ng} / \mathrm{mL}$ and $250 \mathrm{ng} / \mathrm{mL})$, were used as controls. RPMI medium supplemented with FCS (10\%) was added to the lower well as a chemoattractant. After $48 \mathrm{~h}$ of incubation at $37^{\circ} \mathrm{C}$, medium containing noninvading cells was removed from the upper well. Invasive HTR-8/SVneo cells at the lower surface of the insert were washed and fixed with paraformaldehyde (4\%) for $30 \mathrm{~min}$. The nuclei were counterstained with $1 \mu \mathrm{g} / \mathrm{mL}$ Hoechst reagent and visualized with an inverted laser scanning confocal microscope (Leica white light laser TCS SP8-X, Leica Microsystems, Wetzlar, Germany). On each insert, invasive cells were counted on five randomly selected fields by the post-imaging procedure in ImageJ software. Invasive cells were defined as those whose nucleus exceeded $8 \mu \mathrm{m}$ (i.e. the equivalent of a pore size).

\section{Zymography}

After 1, 8 or 15 days of culture (D1, D8 and D15) with differentiation medium in the absence or presence of adiponectin $(25 \mathrm{ng} / \mathrm{mL}$ and $250 \mathrm{ng} / \mathrm{mL})$, total gelatinase activities from ESCs were analyzed by zymography. Aliquots of CM containing $60 \mu \mathrm{g}$ of protein were resolved under non-reducing conditions in $10 \%$ polyacrylamide gels containing $1 \mathrm{mg} / \mathrm{mL}$ gelatin (Difco). Gels were washed in Triton X-100 (2.5\%) for $30 \mathrm{~min}$ to remove SDS and incubated overnight at $37^{\circ} \mathrm{C}$ in a renaturing buffer (50 mM Tris-HCl, pH 7.5, $5 \mathrm{mM} \mathrm{CaCl}_{2}, 150 \mathrm{mM} \mathrm{NaCl}$, and $0.02 \%$ sodium azide). Gels were stained with Coomassie Brilliant Blue, and destained in methanol/acetic acid
$(20 \% / 5 \%$ v/v). Proteolytic activity was identified as a clear band on a blue background. The images were scanned and quantitative enzyme analysis was carried out, using ImageJ software.

\section{Quantitative reverse transcription polymerase chain reaction (RT-qPCR)}

ESCs were seeded in 12-well culture plates $\left(3.5 \times 10^{5}\right.$ cells per well). After 3, 8 or 15 days of differentiation (D3, D8, D15), total RNA $(0.1 \mu \mathrm{g})$ from ESCs was extracted and reverse-transcribed, as previously described (MachinalQuélin et al. 2002). Quantitative PCR was performed using the C1000 Thermal Cycler (CFX96 real-time system; BioRad, Hercules, CA, USA) and the primers sets indicated in Table 1. Final concentration of primers is $25 \mu \mathrm{M}$. The three reference genes, ribosomal protein L13A (RP13), TATA box-binding protein (TBP) and $\beta 2$-microglobulin were chosen as previously described (Benaitreau et al. 2009). For each sample, the concentration ratios (target/ three reference mRNA) were calculated using the BioRad CFX Manager software (version 3.0) and expressed in arbitrary units, as previously described (Duval et al. 2016).

PCR products were separated on a $2 \%$ agarose gel in $90 \mathrm{mM}$ Tris-borate and $2 \mathrm{mM}$ EDTA buffer $(\mathrm{pH} 8.0)$. They were visualized by staining with GelRed (Interchim, Montluçon, France) and UV transillumination.

\section{Immunoblotting}

ESCs were seeded onto 6-well culture plates $\left(2.0 \times 10^{6}\right.$ cells per well) and lysed on ice in buffer containing Tris $(50 \mathrm{mM}), \mathrm{NaCl}(120 \mathrm{mM})$, EDTA $(1 \mathrm{mM})$, Nonidet-P40 $(1 \%)$, deoxycholate $(0.1 \%)$, SDS $(0.1 \%)$, sodium vanadate (1 mM), $\beta$-glycerophosphate ( $30 \mathrm{mM})$, aprotinin $(5 \mu \mathrm{g} / \mathrm{mL})$, leupeptin $(12.5 \mu \mathrm{g} / \mathrm{mL})$, AEBSF $(100 \mu \mathrm{g} / \mathrm{mL})$ and sodium fluoride $(10 \mathrm{mM})$. Twenty micrograms of total proteins were resolved by SDS-PAGE (4-20\% acrylamide) and wet-transferred onto nitrocellulose membranes. Next, the membranes were blocked and incubated overnight with anti-ADIPOR1 (goat anti-human polyclonal, 1:300, sc-46749, Santa Cruz Biotechnology), anti-ADIPOR2 (goat anti-human polyclonal, 1:300, sc-46756, Santa Cruz Biotechnology) or anti- $\beta$-actin (rabbit anti-human monoclonal, 1:500, Sigma Chemical). After washing, the membranes were incubated with the peroxidasecoupled secondary antibody, for $1 \mathrm{~h}$ at room temperature. Blots were developed using the SuperSignal West Pico Chemiluminescent Substrate (Thermo Fisher Scientific). Data were analyzed using ImageJ software.

Published by Bioscientifica Ltd. 
Table 1 Primers used for RT-PCR.

\begin{tabular}{|c|c|c|c|}
\hline Primer set & Sequence & PCR product & Sequence \\
\hline \multicolumn{4}{|l|}{ ADIPOR 1} \\
\hline Sense & 5'TTC TTC CTC ATG GCT GTG ATG T 3' & $71 \mathrm{bp}$ & NM_001290629.1 \\
\hline Antisense & 3'GCT TAA GGA CTC GCG AAG AA 5' & & \\
\hline \multicolumn{4}{|l|}{ ADIPOR2 } \\
\hline Sense & 5'ATA GGG CAG ATA GGC TGG TTG A 3' & 76 bp & NM_024551.2 \\
\hline Antisense & $3^{\prime}$ ACA TAC GAC GGG CCT AGG 5' & & \\
\hline \multicolumn{4}{|c|}{ ADIPONECTIN } \\
\hline Sense & 5'GTC ATT GTC ATT ATC AGC $3^{\prime}$ & $153 \mathrm{bp}$ & NM_004797.3 \\
\hline Antisense & 3'TAT CCA CTT CTC GTA TCG 5' & & \\
\hline \multicolumn{4}{|l|}{ PROLACTIN } \\
\hline Sense & 5'AGC CAG GTT CAT CCT GAA A 3' & $99 \mathrm{bp}$ & NM_000948.5 \\
\hline Antisense & $3^{\prime} \mathrm{TTC}$ TCA GAG CGG AAA GAC GA 5' & & \\
\hline \multicolumn{4}{|c|}{ 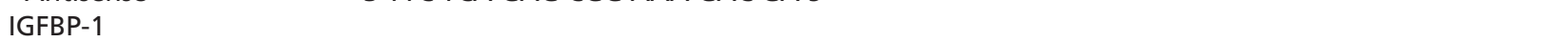 } \\
\hline Sense & 5'ATC ACA GCA GAC AGT GTG AGA 3' & $71 \mathrm{bp}$ & NM_000596.2 \\
\hline Antisense & $3^{\prime}$ CCA CGC AGA TGG GAA CCT TA 5' & & \\
\hline \multicolumn{4}{|c|}{ CONNEXIN-43 } \\
\hline Sense & 5'TTA AGC AAA AGA GTG GTG CCC $3^{\prime}$ & $179 \mathrm{bp}$ & NM_000165.4 \\
\hline Antisense & 3'GAC CCC TCT ACT CGT CAG AC 5' & & \\
\hline \multicolumn{4}{|l|}{ TIMP-3 } \\
\hline Sense & 5'CAC CTC TCC ACG AAG TTG C 3' & $117 \mathrm{bp}$ & NM_000362.4 \\
\hline Antisense & 3'GTG TCT CTG AGA GCC TTC GA 5' & & \\
\hline \multicolumn{4}{|c|}{ encos } \\
\hline Sense & 5'TGC ACA GGA GCC AAG AGT GAA 3' & $132 \mathrm{bp}$ & NM_001172085.1 \\
\hline Antisense & $3^{\prime}$ CAC ATC ACA GCT CCC CAC CA 5' & & \\
\hline \multicolumn{4}{|c|}{ B2-MICROGLOBULIN } \\
\hline Sense & 5'TGC TGT CTC CAT GTT TGA TGT ATC T 3' & $86 b p$ & NM_004048.2 \\
\hline Antisense & 3'TCT CTG CTC CCC ACC TCT AAG T 5' & & \\
\hline \multicolumn{4}{|l|}{ RPL13A } \\
\hline Sense & $5^{\prime} \mathrm{CCT}$ GGA GGA GAA GAG GAA AGA GA 3' & $125 \mathrm{bp}$ & NM_012423.3 \\
\hline Antisense & 3'TTG AGG ACC TCT GTG TAT TTG TCA A 5' & & \\
\hline
\end{tabular}

\section{RNA interference for ADIPOR1 and ADIPOR2}

Two pairs of small-interfering RNAs (siRNAs) corresponding to different regions of each receptor gene were chemically synthesized by Qiagen. The sequences of the sense siRNAs are given in Table 2. A fluorescently labeled, non-silencing control siRNA (siNS) was used to optimize the transfection conditions and as a control for nonspecific silencing effects. For the knockdown experiments, ESCs were plated in 12-well dishes at $3.5 \times 10^{5}$ cells per well. After 13 days, cells were transfected with siNS $(10 \mathrm{nM})$ or siADIPOR $1(25 \mathrm{nM})$ or siADIPOR2 $(25 \mathrm{nM})$ using a Lipofectamine RNAiMAX transfection reagent (Invitrogen) according to the manufacturer's instructions. Adiponectin $(250 \mathrm{ng} / \mathrm{mL})$ was added $24 \mathrm{~h}$ after

Table 2 siRNA sequences.

\begin{tabular}{ll}
\hline Target & $\begin{array}{l}\text { Sequence } \\
\text { ADIPOR1 }\end{array}$ \\
5'AAG GAC AAC GAC TAT CTG CTA 3' \\
5DIPOR2 & 5'ACTG GCT AAA GGA CAA CGA CTA 3' \\
& 5'CGG CTC TCC TTG AAT AAG AAA 3' \\
\hline
\end{tabular}

transfection. mRNA expression was analyzed by RT-qPCR and protein expression was assessed using Western blot, as described previously.

\section{Prolactin secretion}

Prolactin secretion into the culture medium was measured using an automated immuno-chemiluminescence system

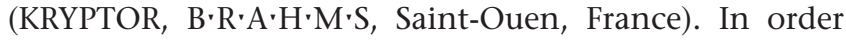
to compare the levels of prolactin secretion, results were normalized to $1 \mu \mathrm{g}$ of total protein. The protein concentration was measured according to Bradford's method, with BSA as the standard.

\section{Statistical analyses}

Statistical analyses were performed on the raw data from 5 to 10 separate experiments. Comparisons between controls (absence of the adiponectin) at D1, D3, D8 and D15, were made using analysis of variance (ANOVA) with Bonferroni $P$ values. A non-parametric, paired Wilcoxon test was used to compare the effect of adiponectin concentration

Published by Bioscientifica Ltd. 

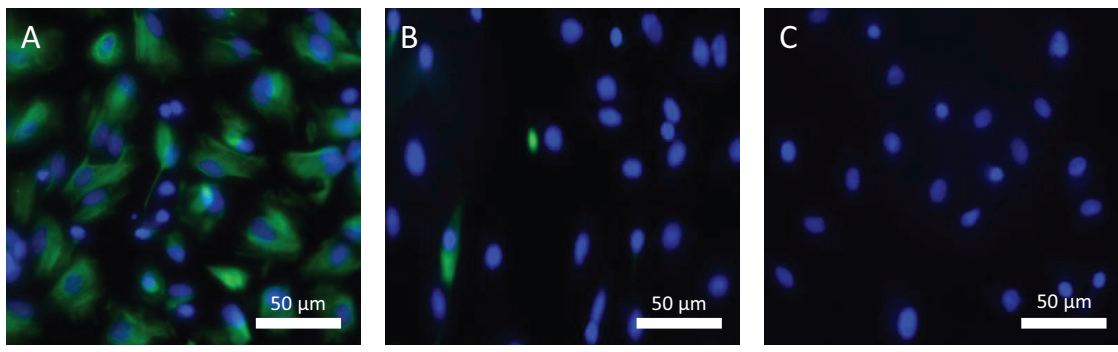

Figure 1

Isolated endometrial cells are human ESCs. After isolation, human endometrial cells were cultured in DMEM/F12 medium supplemented with E2 and P4. Vimentin (a stromal marker) and pancytokeratin (an epithelial marker) were revealed as described in the Materials and methods section. (A) Human endometrial cell stained with anti-vimentin antibody. (B) Human endometrial cell stained with anti-pan-cytokeratin antibody. (C) Negative staining control in the absence of primary antibody. The figure shows one of four separate, representative experiments.

Magnification $\times 40$.
$(25 \mathrm{ng} / \mathrm{mL}$ or $250 \mathrm{ng} / \mathrm{mL}$ ) with the control situation (the absence of adiponectin) for a given day of exposure.

\section{Results}

\section{Characterization of human ESCs}

To assess the purity of our cell preparation, immunocytochemistry experiments were performed, $48 \mathrm{~h}$ after cell isolation. We have studied the expression of vimentin and pan-cytokeratin, which are specific markers of endometrial stroma and epithelium, respectively. Our microscopy analyses revealed that 95\% of isolated endometrial cells stained positive for vimentin and only 5\% expressed pan-cytokeratin (Fig. 1). This clearly demonstrated that the great majority of isolated cells were ESCs. These latter results were confirmed by measuring prolactin secretion into cell culture supernatant, which is a specific marker of ESC decidualization. We showed that this hormonal production increased progressively during cell differentiation $(16 \pm 3,66 \pm 16,571 \pm 157$, and $2374 \pm 607 \mathrm{IU} / \mu \mathrm{g}$ of protein after $1,3,8$, and 15 days of cell culture, respectively).

\section{Expression of adiponectin and its specific receptors in human ESCs}

Human ESCs did not express adiponectin at D3, D8 and D15 of cell decidualization. However, this adipokine was expressed in human adipose tissue, used as a positive control (Fig. 2A). The RT-qPCR results demonstrated that ESCs expressed ADIPOR1 and ADIPOR2, whatever the decidualization status. Furthermore, the respective expression levels were 2.1- and 2.3-fold higher at D15 of cell culture, over D3 (Fig. 2B). Western blot analyses confirmed the presence of the two ADIPOR subtypes in human ESCs, at D3, D8 and D15 of cell decidualization. Human firsttrimester placenta was used as a positive control (Fig. 2C).
A

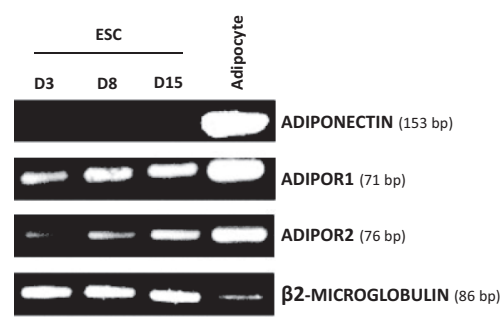

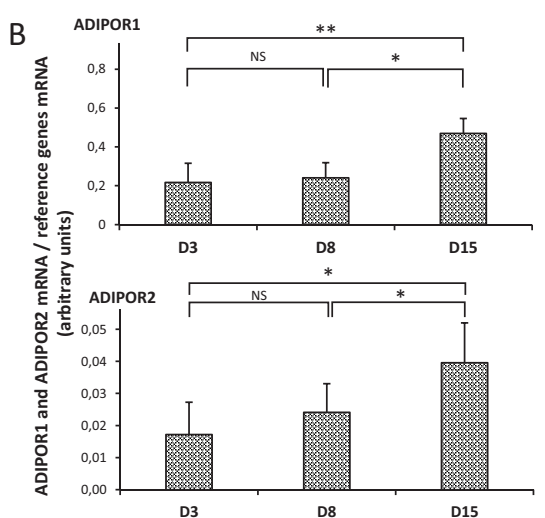

C

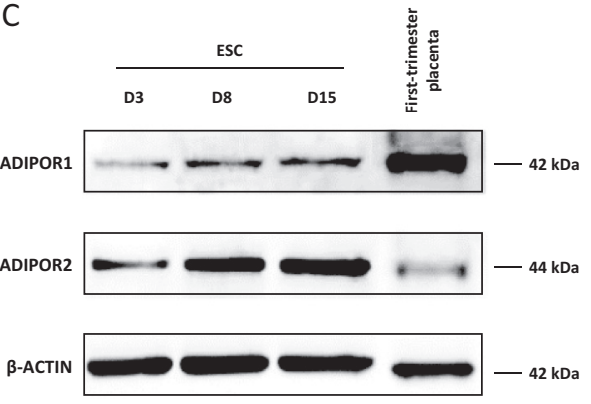

\section{Figure 2}

Adiponectin receptors are expressed in human ESCs. Human ESCs were cultured in DMEM/F12 medium supplemented with E2 and P4. (A) Total RNA was extracted after 3 days (D3), 8 days (D8) and 15 days (D15) of cell differentiation. Adiponectin, ADIPOR1 and ADIPOR2 mRNA expression levels were analyzed by RT-PCR with the primers listed in Table 1. PCR products were analyzed by agarose gel electrophoresis. The figure represents one representative of nine separate experiments. (B) ADIPOR1 and ADIPOR2 mRNA levels were quantified by RT-qPCR as described in Materials and methods section. The data are quoted as the mean \pm s.E.M. of nine separate experiments. (C) Western blot analysis of cell lysates ( $20 \mu g)$ using anti-ADIPOR 1 and anti-ADIPOR2 antibodies, as described in the Materials and methods section. The figure shows one representative of five separate experiments. ${ }^{*} P<0.05$; $* * P<0.01$; NS: non-significant. ANOVA test.

http://jme.endocrinology-journals.org DOI: 10.1530/JME-17-0046
() 2017 The authors Printed in Great Britain
Published by Bioscientifica Ltd 
However, ESC treatment with adiponectin $(25 \mathrm{ng} / \mathrm{mL}$ and $250 \mathrm{ng} / \mathrm{mL}$ ) did not seem to affect $A D I P O R$ expression in these cells (data not shown).

\section{Effect of adiponectin on human ESC decidualization}

Prolactin, IGFBP-1 and CX-43 mRNA expressions and prolactin secretion were used as biochemical markers in order to study the differentiation of ESC into decidual cells. As shown in Fig. 3A, B and C, we observed all along the ESC decidualization process, a significant increasing prolactin, IGFBP-1 and CX-43 mRNA expressions, with a maximal expression at D15 (8.8-fold, 715.2-fold and 3.3-fold increase over D3, respectively). Likewise, we observed a rise in prolactin secretion between D1 and D15 of cell decidualization (118.4-fold) (Fig. 3D). These results validated our in vitro differentiation protocol and showed that ESCs are fully decidualized at D15.

Next, we studied adiponectin effect on decidualization. We did not observe an effect of adiponectin on prolactin mRNA expression, at D3, D8 and D15, for both doses tested (Fig. 3A). However, we showed a drastic decrease in prolactin secretion at D8, in the presence of $250 \mathrm{ng} / \mathrm{mL}$ adiponectin (-25\%) and at D15, for the two doses tested $(-27 \%$ at $25 \mathrm{ng} / \mathrm{mL}$ and $-49 \%$ at $250 \mathrm{ng} / \mathrm{mL}$ ) (Fig. 3D). In presence of adiponectin, we also observed a significant decrease in IGFBP-1 mRNA expression $(-72 \%$ at $25 \mathrm{ng} / \mathrm{mL}$ and $-53 \%$ at $250 \mathrm{ng} / \mathrm{mL})$ and $C X-43$ mRNA expression $(-41 \%$ at $25 \mathrm{ng} / \mathrm{mL}$ and $-37 \%$ at $250 \mathrm{ng} / \mathrm{mL}$ ) at D15 of cell culture only (Fig. 3B and C).
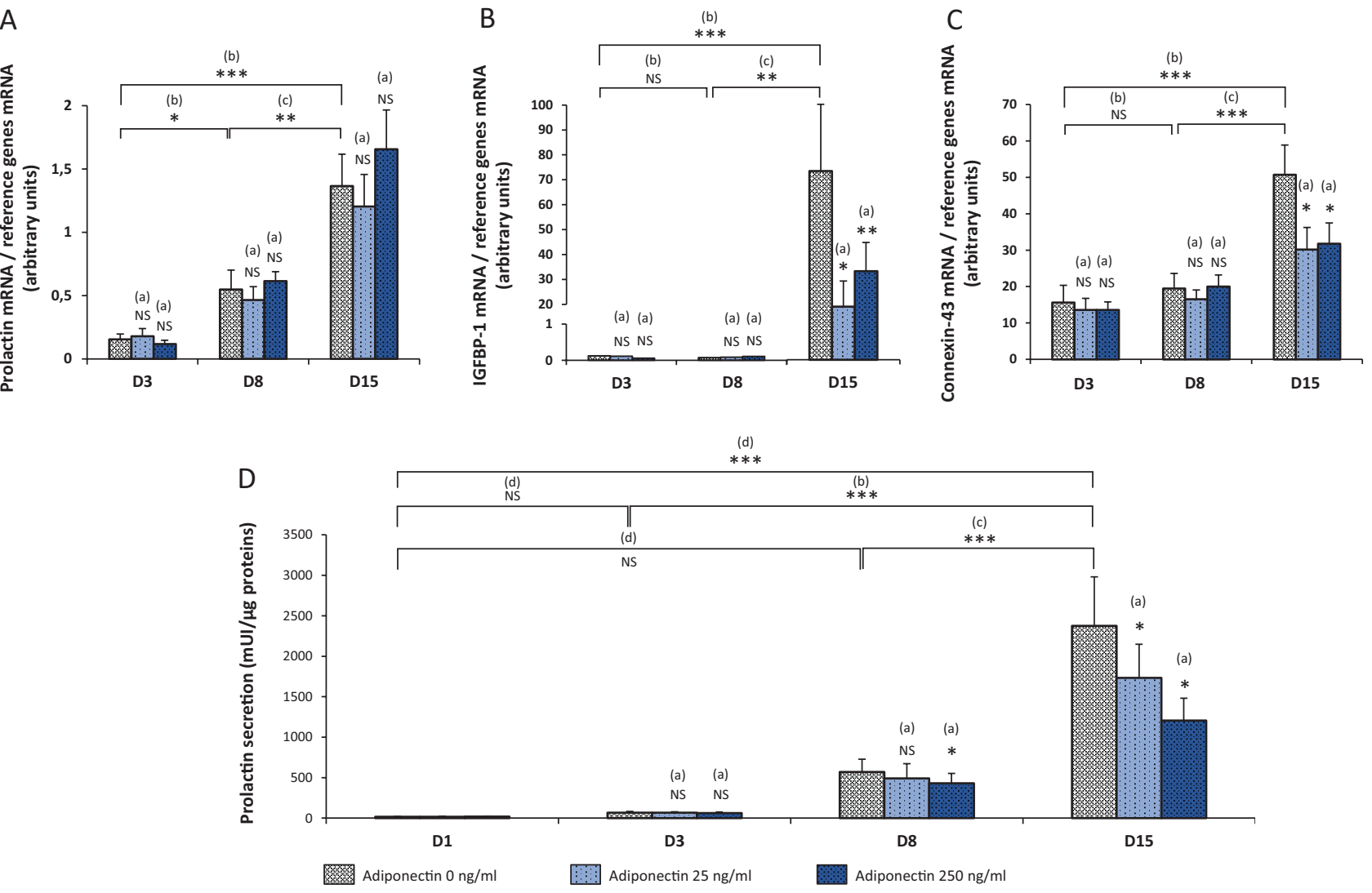

Figure 3

Adiponectin limits ESC decidualization. Human ESCs were cultured in DMEM/F12 medium supplemented with E2 and P4, and exposed or not to adiponectin ( $25 \mathrm{ng} / \mathrm{mL}$ and $250 \mathrm{ng} / \mathrm{mL}$ ) for 15 days. (A, B and C) Total RNA was extracted after 3 days (D3), 8 days (D8) and 15 days (D15) of cell differentiation. Prolactin, IGFBP-1 and connexin-43 mRNA levels were quantified by RT-qPCR, as described in the Materials and methods section. The data are quoted as the mean \pm s.E.M. of nine separate experiments. (A) Prolactin mRNA levels. (B) IGFBP-1 mRNA levels. (C) Connexin-43 mRNA levels. (D) Prolactin secretion into the endometrial supernatants was measured after 1 day (D1), 3 days (D3), 8 days (D8) and 15 days (D15) of cell differentiation, as described in the Materials and methods section. The data are quoted as the mean \pm S.E.M. of ten separate experiments. The control values were $16.75 \pm 3.07,66.34 \pm 16.67,571.35 \pm 157.07$ and $2374.68 \pm 607.50 \mathrm{IU} / \mathrm{g}$ proteins for D1, D3, D8 and D15, respectively. ${ }^{*} P<0.05 ;{ }^{* * P} P<0.01 ; * * * P<0.001 ; \mathrm{NS}$ : non-significant. (A) vs control situation (without adiponectin). Wilcoxon test. (B) vs D3; (C) vs D8; (D) vs D1. ANOVA test.

http://jme.endocrinology-journals.org DOI: 10.1530/JME-17-0046
(C) 2017 The authors Printed in Great Britain
Published by Bioscientifica Ltd 


\section{Involvement of adiponectin in the endometrial control of trophoblast invasion}

In order to determine how adiponectin might be involved in the endometrial control of trophoblast invasion, we performed Matrigel Transwell invasion assays. We cultured the HTR-8/SVneo immortalized EVT cell line in the presence of CM collected from differentiating ESCs treated or not with adiponectin (25 ng/mL and $250 \mathrm{ng} / \mathrm{mL}$ ) for 15 days (Fig. 4A). As shown in Fig. 4B, we observed that $\mathrm{CM}$ from ESCs treated with adiponectin significantly reduced the HTR-8/SVneo cell invasive capacities $(-17 \%$ at $25 \mathrm{ng} / \mathrm{mL}$ and $-32 \%$ at $250 \mathrm{ng} / \mathrm{mL}$ ). In parallel, we performed Matrigel Transwell invasion assays with the HTR-8/SVneo cells in the presence of control medium supplemented or not with adiponectin $(25 \mathrm{ng} / \mathrm{mL}$ and $250 \mathrm{ng} / \mathrm{mL}$ ). As previously described by our laboratory, these experiments confirmed that adiponectin $(250 \mathrm{ng} / \mathrm{mL})$ enhanced trophoblast invasion $(+23 \%)$ (Benaitreau et al. 2010a).
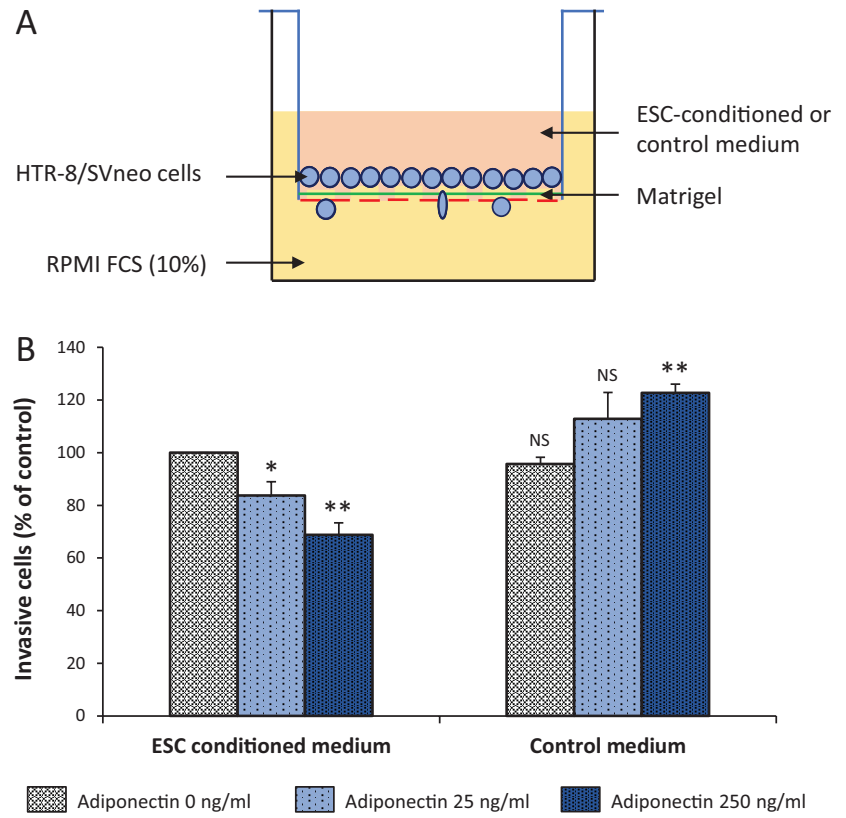

Figure 4

Adiponectin improves the endometrial control of trophoblastic migration. (A) Transwell migration assays of HTR-8/SVneo cells were performed as described in the Materials and methods section. (B) HTR-8/ SVneo cells were suspended in the presence of conditioned medium (CM) from 15-day decidualized ESCs treated or not with adiponectin $(25 \mathrm{ng} / \mathrm{mL}$ and $250 \mathrm{ng} / \mathrm{mL}$ ) or in the presence of control medium, supplemented or not with adiponectin $(25 \mathrm{ng} / \mathrm{mL}$ and $250 \mathrm{ng} / \mathrm{mL})$. The data are quoted as the mean \pm S.E.M. of seven separate experiments. ${ }^{*} P<0.05$; ${ }^{*} P<0.01$; NS: non-significant. Wilcoxon test.

\section{Effect of adiponectin on endometrial TIMP mRNA expression}

We next sought to specify the molecular mechanisms involved in adiponectin anti-invasive action. We focused on the mRNA expression of three invasion inhibitors, such as TIMP-1, TIMP-2, and TIMP-3, strongly expressed in the human endometrium. Using RT-qPCR, we found that TIMP-1 and TIMP-2 mRNA expression did not significantly change throughout ESC decidualization regardless of the presence or absence of adiponectin (data not shown). However, as shown in Fig. 5A, TIMP-3 mRNA expression increased significantly throughout the ESC decidualization process with a peak effect at D15 of cell culture (1.8-fold increase over D3). Furthermore, this increase was amplified by the presence of $25 \mathrm{ng} / \mathrm{mL}$ adiponectin $(+117 \%,+81 \%,+69 \%$, on D3, D8 and D15, respectively) and $250 \mathrm{ng} / \mathrm{mL}$ adiponectin $(+122 \%,+100 \%$ and $+125 \%$ at D3, D8 and D15, respectively).

\section{Effect of adiponectin on endometrial MMP activity}

Zymography assays revealed two bands corresponding to the gelatinase activities of MMP-2 (72 kDa) and MMP-9 $(92 \mathrm{kDa})$ in CM collected on D1, D8 and D15 of cell culture. Both gelatinases showed a higher activity at D8 and D15. An additional band of gelatinase activity ( $45 \mathrm{kDa})$ appeared in CM collected at D1 but had disappeared by D8 and D15 of cell culture (Fig. 5B). Figure 5C and D showed that adiponectin significantly decreased MMP-2 and MMP-9 activities at D8 (-19\% for both MMPs) but only at the higher dose tested. At D15, however, we found that adiponectin downregulated MMP-2 activity (-11\% at $25 \mathrm{ng} / \mathrm{mL}$ and $-15 \%$ at $250 \mathrm{ng} / \mathrm{mL}$ ) and MMP-9 activity $(-28 \%$ at $25 \mathrm{ng} / \mathrm{mL}$ and $-31 \%$ at $250 \mathrm{ng} / \mathrm{mL})$.

\section{Effects of ADIPOR1 and ADIPOR2 knockdown in human ESCs}

Considering the late effect of adiponectin on decidualization (significant at D15 of differentiation), we decided to knockdown ADIPOR1 and ADIPOR2 mRNA expressions with siRNA for the last 2 days of decidualization (from D13 to D15). We observed a significant decrease in ADIPOR1 and ADIPOR2 mRNA expression levels ( -56 and $-58 \%$, respectively) after $48 \mathrm{~h}$ of knockdown. This ADIPOR invalidation was confirmed using Western Blot analysis (Fig. 6). http://jme.endocrinology-journals.org DOI: 10.1530/JME-17-0046
(C) 2017 The authors Printed in Great Britain
Published by Bioscientifica Ltd 

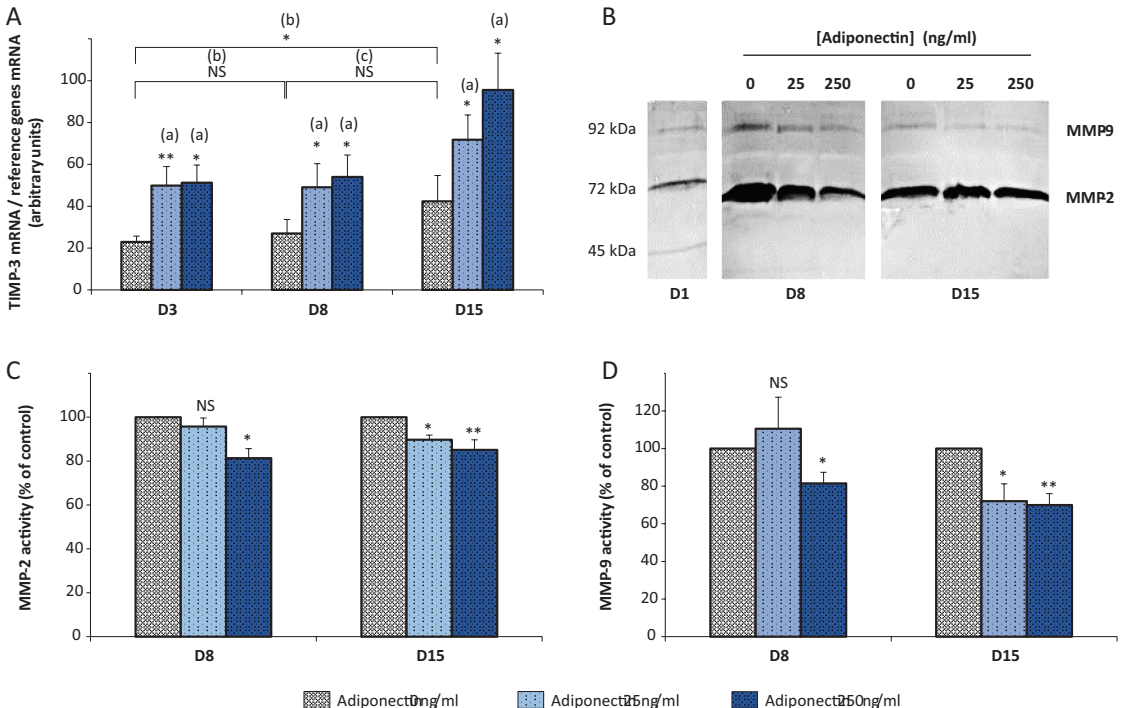

Figure 5

Adiponectin modifies endometrial TIMP expression and MMP activities. Human ESCs were cultured in DMEM/F12 medium supplemented with E2 and P4, and exposed or not to adiponectin $(25 \mathrm{ng} / \mathrm{mL}$ and $250 \mathrm{ng} / \mathrm{mL})$ for 15 days. (A) Total RNA was extracted after 3 days (D3), 8 days (D8) and 15 days (D15) of cell differentiation. The data are quoted as the mean \pm s.E.M. of ten separate experiments.

(B) Activities of gelatinases in conditioned media (CM) from decidualized ESCs after 1 day (D1), 8 days (D8) and 15 days (D15) of cell differentiation were measured as described in the Materials and methods section. This figure shows one representative of seven separate experiments. (C) Quantification of the gelatin zymography results for the MMP-2 band. The data are quoted as the mean \pm S.E.M. of seven separate experiments. (D) Quantification of the gelatin zymography results for the MMP-9 band. The data are quoted as the mean \pm S.E.M. of seven separate experiments. ${ }^{*} P<0.05 ; * * P<0.01$; NS: non-significant. (A) vs control situation (without adiponectin). Wilcoxon test. (B) vs D3, (C) vs D8. ANOVA test.
The partial suppression of ADIPOR1 and ADIPOR2 abolished the decrease of $C X-43$ and IGFBP-1 mRNA expressions observed in the presence of $250 \mathrm{ng} / \mathrm{mL}$ adiponectin (Fig. 7). In parallel, silencing the ADIPOR1 or ADIPOR2 genes suppressed adiponectin $(250 \mathrm{ng} / \mathrm{mL})$ effect on the endometrial control of trophoblast invasion (Fig. 8). These results were also observed when ADIPOR1 and ADIPOR2 were concomitantly invalidated (data not shown).

\section{Discussion}

Effective embryo-maternal communication is the key for a successful pregnancy. Adiponectin is a cytokine described to induce the formation of a functional placenta (Benaitreau et al. 2010a,b). In this study, we sought to examine the role of adiponectin in maternal compartment by studying its effects on decidualization process and endometrial control of trophoblast invasion.
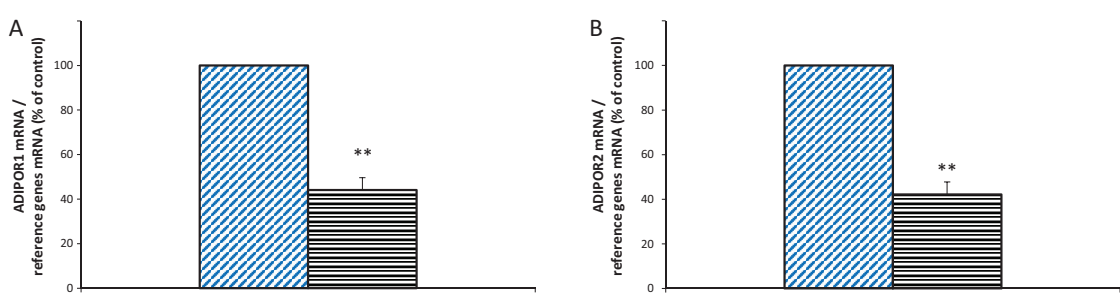

C
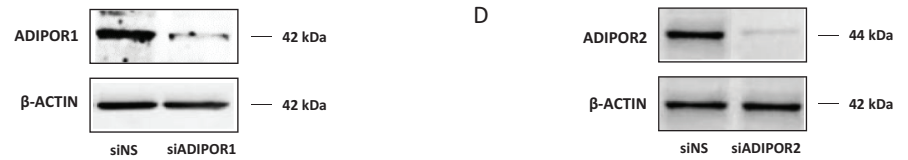

Figure 6

ADIPOR knockdown in human ESCs. Human ESCs were cultured in DMEM/F12 medium supplemented with E2 and P4 for 13 days. Next, ESCs were cultured for 2 days in the presence of siADIPOR1 $(25 \mathrm{nM})$ or siADIPOR2 $(25 \mathrm{nM})$ or siNS $(10 \mathrm{nM})$. (A and B) Total RNA was extracted after treatment and then quantified by RT-qPCR, as described in the Materials and methods. (A) ADIPOR1 mRNA levels. (B) ADIPOR2 mRNA levels. The data are quoted as the mean \pm S.E.M. of six separate experiments. (C and D) Western Blot analysis of cell lysates $(20 \mu \mathrm{g})$ using anti-ADIPOR 1 and anti-ADIPOR2 antibodies, as described in the Materials and methods section. (C) ADIPOR1 protein levels were measured in transfected cells. (D) ADIPOR2 protein levels were measured in transfected cells. The figure represents one representative of four experiments. ${ }^{*} P<0.01$. Wilcoxon test. http://jme.endocrinology-journals.org DOI: 10.1530/JME-17-0046
(C) 2017 The authors Printed in Great Britain
Published by Bioscientifica Ltd. 

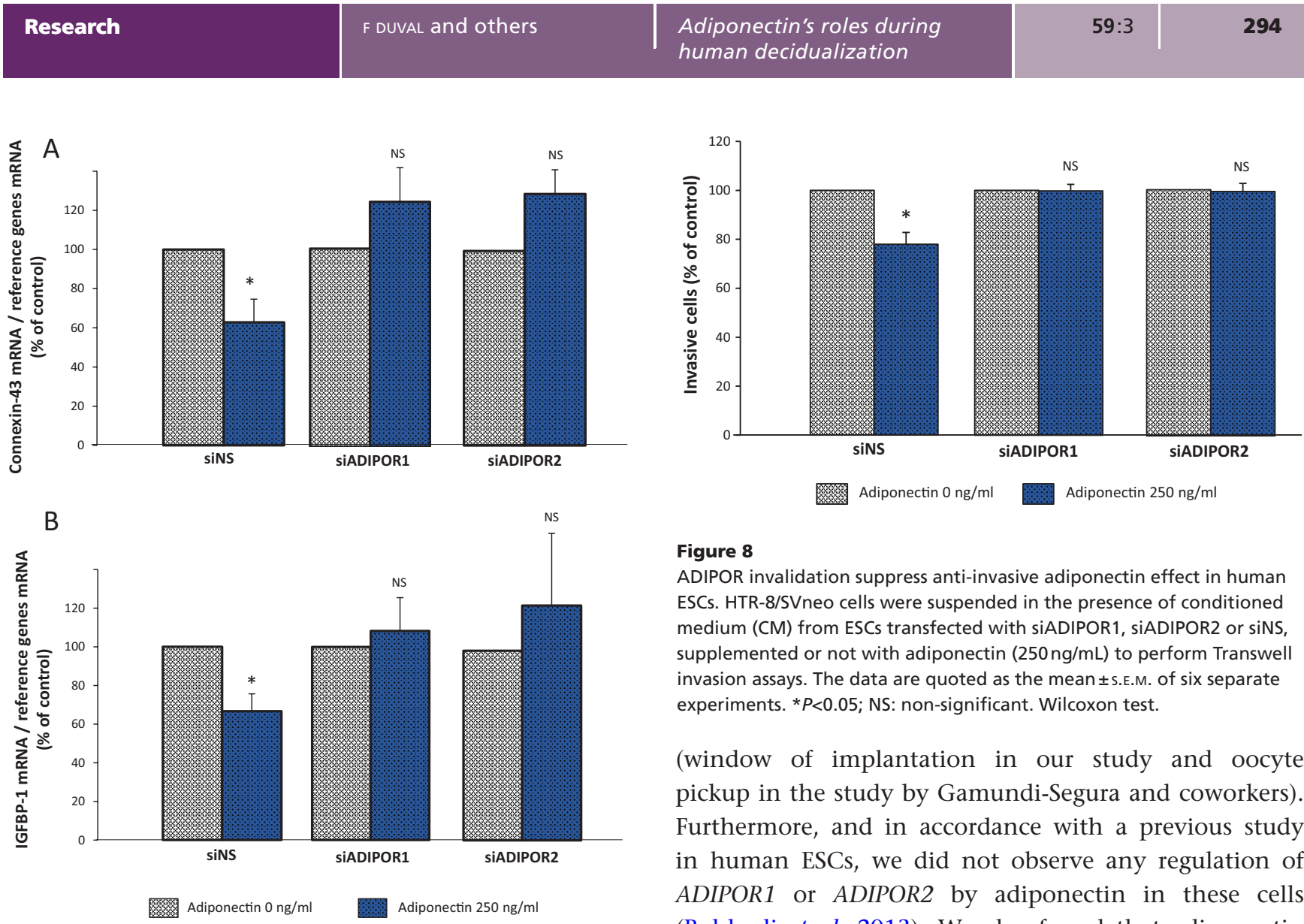

Figure 7

ADIPOR invalidation suppress anti-differentiative adiponectin effect in human ESCs. Human ESCs were cultured in DMEM/F12 medium supplemented with E2 and P4 for 13 days. Next, ESCs were cultured for 2 days in the presence of siADIPOR $1(25 \mathrm{nM})$ or siADIPOR2 $(25 \mathrm{nM})$ or siNS $(10 \mathrm{nM})$. ESCs transfected with siADIPOR1, siADIPOR2 or siNS were exposed or not to adiponectin $(250 \mathrm{ng} / \mathrm{mL}$ ). Total RNA was extracted after treatment and then quantified by RT-qPCR, as described in the Materials and methods section. The data are quoted as the mean \pm S.E.M. of six separate experiments. (A) Connexin-43 mRNA levels were measured in transfected cells. (B) IGFBP-1 mRNA levels were measured in transfected cells. ${ }^{\star} P<0.05$; NS: non-significant. Wilcoxon test.

Firstly, we attempted to determine whether human ESCs transcribe the ADIPOR1 and ADIPOR2 genes. Our results reveal that isolated human ESCs do indeed express these two receptors and strongly suggest that the endometrium is a target tissue for this adipokine. We also observed that ADIPOR1 and ADIPOR2 mRNA levels increased moderately throughout the in vitro endometrial decidualization (with a 2-fold increase between D0 and D15 of decidualization). Our results differ quantitatively from those observed by Gamundi-Segura and coworkers who observed a 10-fold increase in ADIPOR mRNA expression in ESCs during decidualization (GamundiSegura et al. 2015). As the endometrium undergoes major remodeling over the ovarian cycle, this discrepancy might be due to the time point at which the biopsy was performed

\section{Figure 8}

ADIPOR invalidation suppress anti-invasive adiponectin effect in human ESCs. HTR-8/SVneo cells were suspended in the presence of conditioned medium (CM) from ESCs transfected with siADIPOR1, siADIPOR2 or siNS, supplemented or not with adiponectin $(250 \mathrm{ng} / \mathrm{mL})$ to perform Transwell invasion assays. The data are quoted as the mean \pm S.E.M. of six separate experiments. ${ }^{*} P<0.05$; NS: non-significant. Wilcoxon test.

(window of implantation in our study and oocyte pickup in the study by Gamundi-Segura and coworkers). Furthermore, and in accordance with a previous study in human ESCs, we did not observe any regulation of ADIPOR1 or ADIPOR2 by adiponectin in these cells (Bohlouli et al. 2013). We also found that adiponectin did not seem to be produced by isolated human ESCs under our experimental conditions. This result contrasts with previous publications, including ours (Takemura et al. 2006, Dos Santos et al. 2012). However, these earlier studies were performed with endometrial tissue that contains various cell types (stromal cells, epithelial cells, blood vessels, etc.). Detection of adiponectin in endometrial tissue might well have been due to the presence of peripheral blood. Experiments to establish whether isolated endometrial epithelial cells express adiponectin are currently underway in our laboratory.

Secondly, we assessed ESC decidualization by measuring the expression of decidualization markers, as prolactin, IGFBP-1 and connexin-43. We observed a time-dependent increased expression of these three markers (between D3 and D15), in the presence of the differentiation medium, indicating that ESCs are fully differentiated at D15. This result is commonly observed for in vitro ESC decidualization in the presence of $\mathrm{E} 2$ and P4 (Kasahara et al. 2001, Godbole et al. 2011). We also studied adiponectin effect on ESC decidualization. To this end, we used subphysiological doses of recombinant human adiponectin $(25 \mathrm{ng} / \mathrm{mL}$ and $250 \mathrm{ng} / \mathrm{mL})$, which are much lower than those observed in the human circulation. This recombinant human adiponectin effectively mainly 
comprises the high-molecular-weight form (Bub et al. 2006), considered to be the active isoform (Kobayashi et al. 2004). Moreover, adiponectin is commonly used at these concentrations for in vitro experiments with various tissue and cell types (Bråkenhielm et al. 2004, Dos Santos et al. 2008, Duval et al. 2016). Our results clearly show that adiponectin negatively controls biochemical ESC decidualization in a dose-independent manner. We effectively observed a significant decrease of prolactin secretion in ESCs treated with adiponectin. There was no effect on prolactin mRNA expression. This lack of correspondence between RNA and protein levels is not surprising and has been already described (Salari et al. 2012, Beileke et al. 2015). One study specifically evidenced the mismatch between the prolactin mRNA expression and hormone release (Castaño et al. 1997).

Thirdly, we demonstrated that adiponectin downregulates IGFBP-1 and connexin-43 mRNA expression levels. These effects were mainly observed when ESCs were fully differentiated (after 15 days of decidualization). As levels of ADIPOR mRNA doubled between D0 and D15 of decidualization, this observation might explain the delayed, negative effect of adiponectin on decidualization. Taken as a whole, these data suggest that like hCG, leptin and interleukin-1, adiponectin could be a new regulator of human ESC decidualization (Kariya et al. 1991, Kasahara et al. 2001, Tanaka et al. 2003).

As one of the major roles of decidual cells is the control of trophoblast invasion (Godbole et al. 2011, Sharma et al. 2016), we next looked at whether adiponectin could modify the ability of decidualized ESCs to regulate this process. Therefore, we used Transwell assays to estimate the trophoblast HTR-8/SVneo cell line invasive capacities when seeded with CM from ESCs treated or not with adiponectin. Our results clearly demonstrate that CM from ESC cultured in the presence of adiponectin significantly decreased trophoblastic cell ability to invade Matrigel. In order to gain more information at molecular level, we next investigated adiponectin effect on the MMP/ TIMP balance in human ESCs. Our data demonstrate that adiponectin significantly and specifically upregulated TIMP-3 mRNA expression and, conversely, reduced MMP2,-9 activities in ESCs. Thus, it seems that in human endometrium, adiponectin can modulate, at least in part, ECM remodeling via regulation of the MMP-2,-9/TIMP-3 balance. Adiponectin effects on human ESCs were once again dose independent, but is not surprising, since the majority of in vitro studies performed in various cell types such as placental cells, did not show a dose-response effect for adiponectin (Benaitreau et al. 2009, Duval et al. 2016). Taken as a whole, these data suggest that adiponectin induces the production of endometrial factors, which could limit trophoblast invasion. At present, it is difficult to precise whether the secretion of endometrial factors is directly controlled by adiponectin, or indirectly via the induced production of hormones or cytokines. A recent study effectively demonstrated that TNF- $\alpha$ facilitates EVT invasion in vitro by regulating the MMP/TIMP balance in human ESCs (Haider \& Knöfler 2009). Thus, endometrial TNF- $\alpha$ signal could be modified by adiponectin, as described in macrophages and in adipocytes (Tsatsanis et al. 2005, Greenberg \& Obin 2006). Additional experiments will be needed to clarify this hypothesis.

In order to confirm the specific involvement of ADIPOR1 and ADIPOR2 in adiponectin regulation of ESC decidualization and the control of trophoblast invasion, we silenced ADIPORs in ESCs. We found that ADIPOR1 and ADIPOR2 knockdown (separately or concomitantly) suppressed adiponectin anti-differentiative and antiinvasive effects in human ESCs. These results clearly demonstrated the critical involvement of the ADIPORs in adiponectin control of ESC functions.

Lastly, we also attempted to determine whether or not the human ESC decidualization status is associated with the cell ability to control ECM remodeling. We clearly demonstrated that TIMP expression and MMP activities are closely related to ESC decidualization status. Indeed, we confirmed that TIMP-3 mRNA expression significantly rose throughout decidualization, as described by Zhang and Salamonsen (Zhang \& Salamonsen 1997). We also found that non-decidualized ESCs secrete an active MMP, which might be MMP-3. Indeed, MMP-3 is a $45 \mathrm{kDa}$ protein able to digest gelatin. However, the putative MMP-3 activity falls during decidualization. With regard to MMP-9, and more especially MMP-2, which appears to be the most abundantly produced gelatinase in ESCs, we observed an upregulation of their activities during decidualization. These results confirmed that ECM remodeling occurs during ESC differentiation in order to maintain endometrial integrity, which is essential for embryo implantation.

Interestingly, we noted that although adiponectin enhances the MMP/TIMP ratio in human trophoblastic cells, and thus, promotes invasion (Benaitreau et al. 2010a); this adipokine decreases the MMP/TIMP ratio in human ESCs during cell decidualization. This would limit cell migration and consequently avoid excessive invasion. Taken as a whole, these data strongly suggest http://jme.endocrinology-journals.org DOI: 10.1530/JME-17-0046
() 2017 The authors Printed in Great Britain
Published by Bioscientifica Ltd 
that the adiponectin system has a critical role in the establishment of embryo implantation by maintaining the balance of pro-invasive and anti-invasive signals in placenta and endometrium, respectively. In conclusion, it should be noted that dysregulation of the placental invasive potential is associated with several pregnancy pathologies, as spontaneous miscarriages, preeclampsia, intrauterine growth restriction (reduced trophoblast invasion), placenta accreta and choriocarcinoma (excessive trophoblast invasion) (Lala et al. 2002, Anin et al. 2004, Ball et al. 2006, Kadyrov et al. 2006). Hence, our results suggest that adiponectin, through dual control in trophoblast and decidual cells, could have a causative role in the appearance of these pathologies by modulating the invasive capacities.

\section{Declaration of interest}

The authors declare that there is no conflict of interest that could be perceived as prejudicing the impartiality of the research reported.

\section{Funding}

This work was funded by the Institut de Recherche en Santé de la Femme, based at the UFR des Sciences de la Santé, University of Versailles - Saint Quentin en Yvelines.

\section{Author contribution statement}

$F D$ and $M N D$ designed the experiments. $F D$ and $H M$ performed the experiments. F D and MND analyzed the data. F D, MN D and E D S wrote the manuscript. N S B provided human endometrial biopsies for experiments. V S performed automated quantifications. F V participated in critical revision of the manuscript.

\section{Acknowledgements}

The authors gratefully acknowledge the staff at the Department of Gynecology and Obstetrics at $\mathrm{CHI}$ de Poissy-Saint-Germain, for kindly human endometrial biopsies available. They thank Guillaume Groffe for technical support. Immunofluorescence image acquisition and analysis were performed at the CYMAGES facility, supported by the Saint-Quentinen-Yvelines Urban Community and the University of Versailles-SaintQuentin-en-Yvelines.

\section{References}

Anin SA, Vince G \& Quenby S 2004 Trophoblast invasion. Human Fertility 7 169-174. (doi:10.1080/14647270400006911)

Ball E, Bulmer JN, Ayis S, Lyall F \& Robson SC 2006 Late sporadic miscarriage is associated with abnormalities in spiral artery transformation and trophoblast invasion. Journal of Pathology 208 535-542. (doi:10.1002/path.1927)

Beileke S, Claassen H, Wagner W, Matthies C, Ruf C, Hartmann A, Garreis F, Paulsen F, Schicht M \& Bräuer L 2015 Expression and localization of lung surfactant proteins in human testis. PLOS ONE 10 e0143058. (doi:10.1371/journal.pone.0143058)

Benaitreau D, Dieudonné M-N, Dos Santos E, Leneveu M-C, de Mazancourt P \& Pecquery R 2009 Antiproliferative effects of adiponectin on human trophoblastic cell lines JEG-3 and BeWo. Biology of Reproduction 80 1107-1114. (doi:10.1095/ biolreprod.108.070573)

Benaitreau D, Dos Santos E, Leneveu M-C, Alfaidy N, Feige J-J, de Mazancourt P, Pecquery R \& Dieudonné M-N 2010a Effects of adiponectin on human trophoblast invasion. Journal of Endocrinology 207 45-53. (doi:10.1677/JOE-10-0170)

Benaitreau D, Dos Santos E, Leneveu M-C, De Mazancourt P, Pecquery R \& Dieudonné M-N 2010b Adiponectin promotes syncytialisation of BeWo cell line and primary trophoblast cells. Reproductive Biology and Endocrinology 8 128. (doi:10.1186/1477-7827-8-128)

Bohlouli S, Khazaei M, Teshfam M \& Hassanpour H 2013 Adiponectin effect on the viability of human endometrial stromal cells and mRNA expression of adiponectin receptors. International Journal of Fertility and Sterility 7 43-48.

Bråkenhielm E, Veitonmäki N, Cao R, Kihara S, Matsuzawa Y, Zhivotovsky B, Funahashi T \& Cao Y 2004 Adiponectin-induced antiangiogenesis and antitumor activity involve caspase-mediated endothelial cell apoptosis. PNAS 101 2476-2481. (doi:10.1073/ pnas.0308671100)

Brar AK, Frank GR, Richards RG, Meyer AJ, Kessler CA, Cedars MI, Klein DJ \& Handwerger S 1995 Laminin decreases PRL and IGFBP-1 expression during in vitro decidualization of human endometrial stromal cells. Journal of Cellular Physiology 163 30-37. (doi:10.1002/jcp.1041630105)

Bub JD, Miyazaki T \& Iwamoto Y 2006 Adiponectin as a growth inhibitor in prostate cancer cells. Biochemical and Biophysical Research Communications 340 1158-1166. (doi:10.1016/j.bbrc.2005.12.103)

Burrows TD, King A \& Loke YW 1996 Trophoblast migration during human placental implantation. Human Reproduction Update $\mathbf{2}$ 307-321. (doi:10.1093/humupd/2.4.307)

Campos DB, Palin M-F, Bordignon V \& Murphy BD 2008 The 'beneficial' adipokines in reproduction and fertility. International Journal of Obesity 32 223-231. (doi:10.1038/sj.ijo.0803719)

Castaño JP, Faught WJ, Glavé EE, Russell BS \& Frawley LS 1997 Discordance of prolactin gene transcription, mRNA storage, and hormone release in individual mammotropes. American Journal of Physiology 272 E390-E396.

Diedrich K, Fauser BCJM, Devroey P \& Griesinger G 2007 The role of the endometrium and embryo in human implantation. Human Reproduction Update 13 365-377. (doi:10.1093/humupd/dmm011)

Dieudonne M-N, Bussiere M, Dos Santos E, Leneveu M-C, Giudicelli Y \& Pecquery R 2006 Adiponectin mediates antiproliferative and apoptotic responses in human MCF7 breast cancer cells. Biochemical and Biophysical Research Communications 345 271-279. (doi:10.1016/j.bbrc.2006.04.076)

Dos Santos E, Benaitreau D, Dieudonne M-N, Leneveu M-C, Serazin V, Giudicelli Y \& Pecquery R 2008 Adiponectin mediates an antiproliferative response in human MDA-MB 231 breast cancer cells. Oncology Reports 20 971-977. (doi:10.3892/or.00000098)

Dos Santos E, Serazin V, Morvan C, Torre A, Wainer R, De Mazancourt P \& Dieudonné MN 2012 Adiponectin and leptin systems in human endometrium during window of implantation. Fertility and Sterility 97 771-8.e1. (doi:10.1016/j.fertnstert.2011.12.042)

Duval F, Dos Santos E, Poidatz D, Sérazin V, Gronier H, Vialard F \& Dieudonné M-N 2016 Adiponectin inhibits nutrient transporters and promotes apoptosis in human villous cytotrophoblasts: involvement in the control of fetal growth. Biology of Reproduction. (doi:10.1095/ biolreprod.115.134544)

Estella C, Herrer I, Atkinson SP, Quiñ onero A, Martínez S, Pellicer A, Simó C \& Wang H 2012 Inhibition of histone deacetylase activity in human endometrial stromal cells promotes extracellular matrix http://jme.endocrinology-journals.org

DOI: 10.1530/JME-17-0046
(C) 2017 The authors Printed in Great Britain
Published by Bioscientifica Ltd 
remodelling and limits embryo invasion. PLoS ONE 7 e30508. (doi:10.1371/journal.pone.0030508)

Gamundi-Segura S, Serna J, Oehninger S, Horcajadas JA \& Arbones-Mainar JM 2015 Effects of adipocyte-secreted factors on decidualized endometrial cells: modulation of endometrial receptivity in vitro. Journal of Physiology and Biochemistry $\mathbf{7 1}$ 537-546. (doi:10.1007/s13105-015-0393-0)

Godbole G, Suman P, Gupta SK \& Modi D 2011 Decidualized endometrial stromal cell derived factors promote trophoblast invasion. Fertility and Sterility 95 1278-1283. (doi:10.1016/j.fertnstert.2010.09.045)

Gonzalez RR, Palomino A, Boric A, Vega M \& Devoto L 1999 A quantitative evaluation of alpha1, alpha4, alphaV and beta3 endometrial integrins of fertile and unexplained infertile women during the menstrual cycle. A flow cytometric appraisal. Human Reproduction 14 2485-2492. (doi:10.1093/humrep/14.10.2485)

Greenberg AS \& Obin MS 2006 Obesity and the role of adipose tissue in inflammation and metabolism. American Journal of Clinical Nutrition 83 461S-465S.

Grewal S, Carver JG, Ridley AJ \& Mardon HJ 2008 Implantation of the human embryo requires Rac1-dependent endometrial stromal cell migration. PNAS 105 16189-16194. (doi:10.1073/pnas.0806219105)

Haider S \& Knöfler M 2009 Human tumour necrosis factor: physiological and pathological roles in placenta and endometrium. Placenta 30 111-123. (doi:10.1016/j.placenta.2008.10.012)

Huppertz B, Kertschanska S, Demir AY, Frank HG \& Kaufmann P 1998 Immunohistochemistry of matrix metalloproteinases (MMP), their substrates, and their inhibitors (TIMP) during trophoblast invasion in the human placenta. Cell and Tissue Research 291 133-148. (doi:10.1007/s004410050987)

Kadyrov M, Kingdom JCP \& Huppertz B 2006 Divergent trophoblast invasion and apoptosis in placental bed spiral arteries from pregnancies complicated by maternal anemia and early-onset preeclampsia/ intrauterine growth restriction. American Journal of Obstetrics and Gynecology 194 557-563. (doi:10.1016/j.ajog.2005.07.035)

Kariya M, Kanzaki H, Takakura K, Imai K, Okamoto N, Emi N, Kariya Y \& Mori T 1991 Interleukin-1 inhibits in vitro decidualization of human endometrial stromal cells. Journal of Clinical Endocrinology and Metabolism 73 1170-1174. (doi:10.1210/jcem-73-6-1170)

Kasahara K, Takakura K, Takebayashi K, Kimura F, Nakanishi K \& Noda Y 2001 The role of human chorionic gonadotropin on decidualization of endometrial stromal cells in vitro. Journal of Clinical Endocrinology and Metabolism 86 1281-1286. (doi:10.1210/jcem.86.3.7281)

Kern PA, Di Gregorio GB, Lu T, Rassouli N \& Ranganathan G 2003 Adiponectin expression from human adipose tissue: relation to obesity, insulin resistance, and tumor necrosis factor-alpha expression. Diabetes 52 1779-1785. (doi:10.2337/diabetes.52.7.1779)

Kobayashi H, Ouchi N, Kihara S, Walsh K, Kumada M, Abe Y, Funahashi T \& Matsuzawa Y 2004 Selective suppression of endothelial cell apoptosis by the high molecular weight form of adiponectin. Circulation Research 94 e27-e31. (doi:10.1161/01. RES.0000119921.86460.37)

Lala PK, Lee BP, Xu G \& Chakraborty C 2002 Human placental trophoblast as an in vitro model for tumor progression. Canadian Journal of Physiology and Pharmacology 80 142-149. (doi:10.1139/y02-006)

Lunghi L, Ferretti ME, Medici S, Biondi C \& Vesce F 2007 Control of human trophoblast function. Reproductive Biology and Endocrinology 5 6. (doi:10.1186/1477-7827-5-6)

Machinal-Quélin F, Dieudonné MN, Leneveu MC, Pecquery R \& Giudicelli Y 2002 Proadipogenic effect of leptin on rat preadipocytes in vitro: activation of MAPK and STAT3 signaling pathways. American Journal of Physiology 282 C853-C863. (doi:10.1152/ajpcell.00331.2001)
Merviel P, Degeorges A, Salat-Baroux J \& Calvo F 1995 Normal human endometrial cells in culture: characterization and immortalization of epithelial and stromal cells by SV 40 large T antigen. Biology of the Cell 84 187-193. (doi:10.1016/0248-4900(96)89428-7)

Nissi R, Talvensaari-Mattila A, Kotila V, Niinimäki M, Järvelä I, Turpeenniemi-Hujanen T, Staun-Ram E, Goldman S, Gabarin D, Shalev E, et al. 2013 Circulating matrix metalloproteinase MMP-9 and MMP-2/TIMP-2 complex are associated with spontaneous early pregnancy failure. Reproductive Biology and Endocrinology 112. (doi:10.1186/1477-7827-11-2)

Salari R, Wojtowicz D, Zheng J, Levens D, Pilpel Y, Przytycka TM, Elowitz M, Levine A, Siggia E, Swain P, et al. 2012 Teasing apart translational and transcriptional components of stochastic variations in eukaryotic gene expression. PLoS Computational Biology 8 e1002644. (doi:10.1371/journal.pcbi.1002644)

Sharma S, Godbole G \& Modi D 2016 Decidual control of trophoblast invasion. American Journal of Reproductive Immunology 75 341-350. (doi:10.1111/aji.12466)

Singh M, Chaudhry P \& Asselin E 2011 Bridging endometrial receptivity and implantation: network of hormones, cytokines, and growth factors. Journal of Endocrinology 210 5-14. (doi:10.1530/JOE-10-0461)

Staun-Ram E, Goldman S, Gabarin D \& Shalev E 2004 Expression and importance of matrix metalloproteinase 2 and 9 (MMP-2 and -9) in human trophoblast invasion. Reproductive Biology and Endocrinology 2 59. (doi:10.1186/1477-7827-2-59)

Takemura Y, Osuga Y, Yamauchi T, Kobayashi M, Harada M, Hirata T, Morimoto C, Hirota Y, Yoshino O, Koga K, et al. 2006 Expression of adiponectin receptors and its possible implication in the human endometrium. Endocrinology 147 3203-3210. (doi:10.1210/en.2005-1510)

Tanaka T, Utsunomiya T, Bai T, Nakajima S \& Umesaki N 2003 Leptin inhibits decidualization and enhances cell viability of normal human endometrial stromal cells. International Journal of Molecular Medicine 12 95-98. (doi:10.3892/ijmm.12.1.95)

Tapia-Pizarro A, Argandoña F, Palomino WA \& Devoto L 2013 Human chorionic gonadotropin (hCG) modulation of TIMP1 secretion by human endometrial stromal cells facilitates extravillous trophoblast invasion in vitro. Human Reproduction 28 2215-2227. (doi:10.1093/ humrep/det136)

Tsatsanis C, Zacharioudaki V, Androulidaki A, Dermitzaki E, Charalampopoulos I, Minas V, Gravanis A \& Margioris AN 2005 Adiponectin induces TNF- $\alpha$ and IL- 6 in macrophages and promotes tolerance to itself and other pro-inflammatory stimuli. Biochemical and Biophysical Research Communications 335 1254-1263. (doi:10.1016/j.bbrc.2005.07.197)

Yamauchi T, Kamon J, Ito Y, Tsuchida A, Yokomizo T, Kita S, Sugiyama T, Miyagishi M, Hara K, Tsunoda M, et al. 2003a Cloning of adiponectin receptors that mediate antidiabetic metabolic effects. Nature 423 762-769. (doi:10.1038/nature01705)

Yamauchi T, Hara K, Kubota N, Terauchi Y, Tobe K, Froguel P, Nagai R \& Kadowaki T $2003 b$ Dual roles of adiponectin/Acrp30 in vivo as an anti-diabetic and anti-atherogenic adipokine. Current Drug Targets 3 243-254. (doi:10.2174/1568008033340090)

Yu J, Wu J, Bagchi IC, Bagchi MK, Sidell N \& Taylor RN 2011 Disruption of gap junctions reduces biomarkers of decidualization and angiogenesis and increases inflammatory mediators in human endometrial stromal cell cultures. Molecular and Cellular Endocrinology 344 25-34. (doi:10.1016/j.mce.2011.04.011)

Zhang J \& Salamonsen LA 1997 Tissue inhibitor of metalloproteinases (TIMP)-1, -2 and -3 in human endometrium during the menstrual cycle. Molecular Human Reproduction 3 735-741. (doi:10.1093/ molehr/3.9.735)

Received in final form 12 July 2017

Accepted 21 July 2017

Accepted Preprint published online 21 July 2017 http://jme.endocrinology-journals.org

DOI: 10.1530/JME-17-0046
(C) 2017 The authors Printed in Great Britain
Published by Bioscientifica Ltd 